\title{
Genetic Algorithm with Baker's SUS Selection for Shift Scheduling of the Security Officers at Rawa Buntu Train Station, Indonesia
}

\author{
Aghistina Kartika Dewi ${ }^{1}$, Achmad Solichin ${ }^{2}$ \\ \{aghistinakd@gmail.com ${ }^{1}$, achmad.solichin@budiluhur.ac.id $\left.{ }^{2}\right\}$ \\ Post Graduate of Computer Science, Universitas Budi Luhur, Jakarta, Indonesia ${ }^{1}$, Faculty of \\ Information Technology, Universitas Budi Luhur, Jakarta, Indonesia ${ }^{2}$
}

\begin{abstract}
The increase of railway passengers in Indonesia should be balanced with security and convenience, especially at departure and train arrival stations. In ensuring passenger safety, PT Kereta Api Indonesia (KAI) provides some security officers at each railway station, including the Rawa Buntu Station. The Station Head and the Security Commander are responsible for drafting a guard schedule for 30 security officers at the station. The security schedule is divided into three shifts and eight guard locations. Manually arranged schedules often result in unbalanced work hours, clashing schedules and allowing emptiness of security officers. It is getting harder with additional rules that whenever a security guard gets a night shift, the next day must be off. In this research, we proposed a shift scheduling method based on a genetic algorithm using Stochastic Universal Sampling (SUS) selection method, double point crossover, random mutation and using generational model (elitism) for its generation update process. This research produces an application that can assist in the preparation of automatic shift scheduling of the security officers. Based on the test results, the application can arrange the schedule with the suitability level of $70 \%$ and the average time needed to generate schedule is 72.48 seconds. With this research, the process of arranging the schedule of security officers at the Rawa Buntu Station to be faster.
\end{abstract}

Keywords: Transportation, shift scheduling, GA, Stochastic Universal Sampling.

\section{Introduction}

In the railway transport system, the station is one of the most important facilities. The station is used as a departure and arrival point of train passengers, so it has a high level of the crowd. The crowd of the station increases during the morning and afternoon, which is the time to leave and go home for many urban workers. Data from the Jakarta Central Bureau of Statistics show that in 2015 the number of train passengers reaches 700 thousand passengers per day [1]. As one of the railway stations in Jakarta and surrounding areas, the Rawa Buntu Station is one of the most crowded stations. 
With the crowd of the railway station, of course, the safety issues of the passengers should be a top priority. Currently, the Rawa Buntu Station has several security officers on duty in turn to maintain security at the station. Also, officers are also responsible for managing passenger mobility bypassing, preventing riots or commotion, preventing and arranging passengers who want to cross the railway, and setting up safety signs when railway doors are closed.

Limitations on the number of security officers require the setting up of an effective and efficient guard schedule. The Security Commander (its call 'Danru') that appointed by the Station Head is responsible for drafting the security guard's schedule each month. Currently, the schedule is arranged manually which takes a long time. Difficulties encountered include how to present the distribution of shifts evenly, balanced and fair. Within one working day, 'Danru' has to divide 30 members of the security officers to guard in the morning and afternoon shift with the number of officers each of 8 to 10 people. As for the night shift, there are at least 4 to 6 security officers. The officers who do not get shift will get a day off. If an officer has been on guard for five days, then he/she must get a day off for two days successively. Other than that, after an officer gets a night shift, he/she should not be on guard the next morning.

Many methods can be used to solve the scheduling problem. One way is to use the concept of genetic algorithms inspired by Darwin's theory of evolution. The genetic algorithm (GA) is a search algorithm based on the mechanism of natural selection and natural genetics [2],[3]. The best individuals will survive and have a higher reproductive rate when compared to the less-favored individuals. At a certain time (generation), the population as a whole will contain more organisms that have the best properties, where the properties are from good parents as well.

The genetic algorithm incorporates a persistent string structure to form a new search algorithm. In each generation, a number of new individuals are created through the strong parts of their parents. There are several terms used in the genetic algorithm. The term strings in an artificial genetic system are analogous to chromosomes in biological systems. In biological systems, chromosomes are combined to form a genetic recipe as a whole. This genetic concept is used for the formation and operation of several organisms [2],[3]. In the natural system, the entire genetic package is called genotype. In artificial systems, the whole package of strings is called a structure. In the natural system, the organism is formed by the interaction of the entire genetic package with its environment called phenotype. In an artificial genetic system, the structure is decoded to form parameter packets, alternatives, solutions or points in the solution space.

In the natural system, chromosomes consist of genes, which consist of some values called alleles. In genetics, the position of a gene is identified separately from the function of the gene.

GAs have been widely applied to solve various problems in the field of technology, business, agriculture, entertainment and other fields. Some examples of the use of genetic algorithms include optimization of scheduling, automatic programming, machine learning, economic model, immunization system model, ecological model, and interaction between evolution and learning [4]. Table 1 presents various studies related to the application of genetic algorithms, especially to solve the scheduling problem. In previous research, genetic algorithms have been widely implemented to solve the problem of scheduling in various fields. Nevertheless, no studies have applied a genetic algorithm to complete scheduling of security officers who have complexity and special rules such as at railway stations. 
In this study, we applied GA to optimize the preparation of security guard shift schedule at the Rawa Buntu Station. The process of preparation of the schedule is done with several considerations: the number of security officers, shift work time, and the location of the guard. By applying the GA method, it is expected that the time required for the preparation of the security officers' shift schedule is faster than before. It is expected to be more equitable, balanced and fair. The preparation of the work shift schedule is made for the period per one month with the fulfillment of shift per day. Each work shift made has a reasonable minimum and maximum limits. Before the application is executed and the best solution is obtained, it is assumed that no security officer is applying for a day off.

\section{Research Method}

The main problem raised in this research is the duration of the process of drafting the security guard duty schedule at the train station. A total of 30 security officers should be divided into three shift guards, i.e., morning, noon and night. The guard area is divided into 8 locations, so at each shift ideally, there are at least eight duty officers. However, especially for the night, the security guard is only about 4-6 people because at night the density of the station will be reduced.

Based on observations and interviews with related parties, several provisions must be met in the arrangement of the guard schedule. First, if the officer has been on watch for five days, then the officer will get a day off for two consecutive days. Secondly, after an officer gets a night watch, it should not be on the morning watch the next day. Third, in one location or guard area, there is only one duty officer. In other words, there should be no clock clash.

In this study, it is proposed the application of shift scheduling guard the security guard using the concept of genetic algorithm. In the genetic algorithm, there are several basic stages of early population generation, selection, and crossover, mutation, and generation updates. The proposed selection method is the Stochastic Universal Sampling (SUS) method with zero bias and minimal spreads [5]. The SUS selection method is considered to be better and more optimal than the Roullete Wheel method because it involves only the desired number of individuals [6]. Meanwhile, in this study used the method of double-point-crossover, random mutation, and elitism for its generation update process.

Tabel 1. Related research in GA implementation.

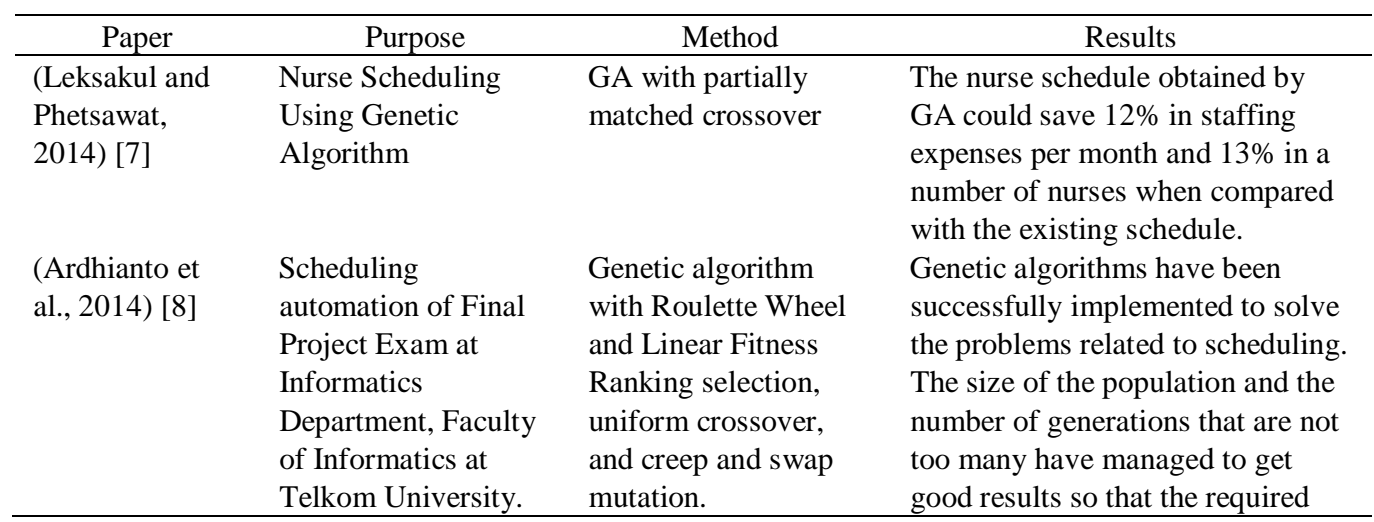




\begin{tabular}{|c|c|c|c|}
\hline & & & $\begin{array}{l}\text { less process time. Experiments } \\
\text { show an accuracy rate of } 74 \% \text { to } \\
88 \% \text {. }\end{array}$ \\
\hline $\begin{array}{l}\text { (Hariyadi et al., } \\
\text { 2016) [9] }\end{array}$ & $\begin{array}{l}\text { Optimization of } \\
\text { academic scheduling } \\
\text { system at university }\end{array}$ & $\begin{array}{l}\text { Genetic algorithm } \\
\text { with tournament } \\
\text { selection. }\end{array}$ & $\begin{array}{l}\text { A genetic algorithm has been } \\
\text { successfully implemented to solve } \\
\text { the academic schedule at the State } \\
\text { University of Malang. It shows } \\
\text { that GA can perform with the } \\
\text { fitness value } 0.952 \text { in the training } \\
\text { phase and } 0.927 \text { in the testing } \\
\text { phase. However, the execution } \\
\text { time is still high and still need } \\
\text { improvement in the future } \\
\text { research. }\end{array}$ \\
\hline $\begin{array}{l}\text { (Sari et al., } \\
\text { 2015) [10] }\end{array}$ & $\begin{array}{l}\text { Optimization of } \\
\text { subject scheduling }\end{array}$ & $\begin{array}{l}\text { GA with Roulette } \\
\text { Wheel selection, one- } \\
\text { cut-point crossover, } \\
\text { reciprocal exchange } \\
\text { mutation, and Elitism } \\
\text { generation update. }\end{array}$ & $\begin{array}{l}\text { From the results of the tests, the } \\
\text { best results obtained with the } \\
\text { highest fitness value on the } \\
\text { number of } 80 \text { th generation, } \\
\text { number of population } 60 \text {, and } \\
\text { combination of crossover rate and } \\
\text { mutation rate of } 0.4: 0.6 \text {. }\end{array}$ \\
\hline $\begin{array}{l}\text { (Prasetyo, 2014) } \\
{[11]}\end{array}$ & $\begin{array}{l}\text { GA and artificial } \\
\text { neural network for } \\
\text { course scheduling at } \\
\text { FMIPA Universitas } \\
\text { Gadjah Mada. }\end{array}$ & $\begin{array}{l}\text { GA with Roulette } \\
\text { Wheel selection, n- } \\
\text { point crossover, and } \\
\text { random mutation. }\end{array}$ & $\begin{array}{l}\text { The combination of proper input } \\
\text { parameters in the process of } \\
\text { implementing GA and neural } \\
\text { network in case of course } \\
\text { scheduling at FMIPA UGM can } \\
\text { produce more optimal prediction } \\
\text { result. }\end{array}$ \\
\hline
\end{tabular}

Figure 1 shows the genetic algorithm process proposed in this study. In the early stages, the system will retrieve data on shift constraints, holiday patterns, periods and timing of the schedule. Next will be established initial population based on the number of available work shifts. The initial population will calculate its fitness value. If the population has met all the criteria, then the population becomes the final population. But if you do not meet the criteria, do the selection process with SUS method, crossover with double-point crossover method, and random mutation to find better population. 


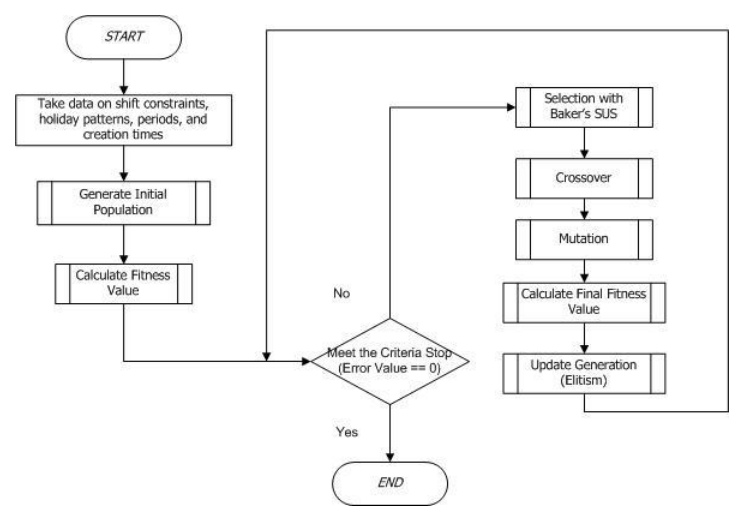

Fig. 1. The proposed Genetic Algorithm process.

\section{Results And Discussion}

\subsection{The Application}

This study produced an application to generate a security guard duty schedule by implementing a genetic algorithm. The main view of the application is shown in Figure 2. To generate a new schedule, user can fill in some parameters including schedule period, daily shift number, and holiday shift model. Furthermore, when user press the "Create" button, then the system will run the genetic algorithm and generate a schedule as shown in Figure 3.

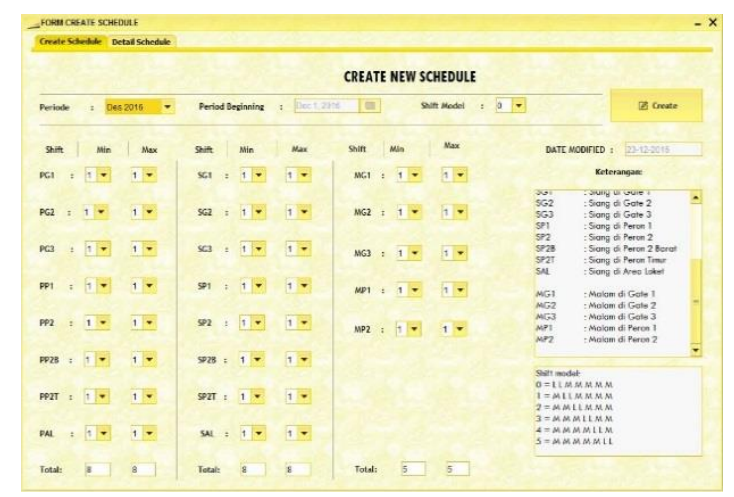

Fig. 2. Main view of the application to create new schedule.

In addition to viewing them directly in the application, users can also save schedules that have been created into the database or save them in Microsoft Excel format. 


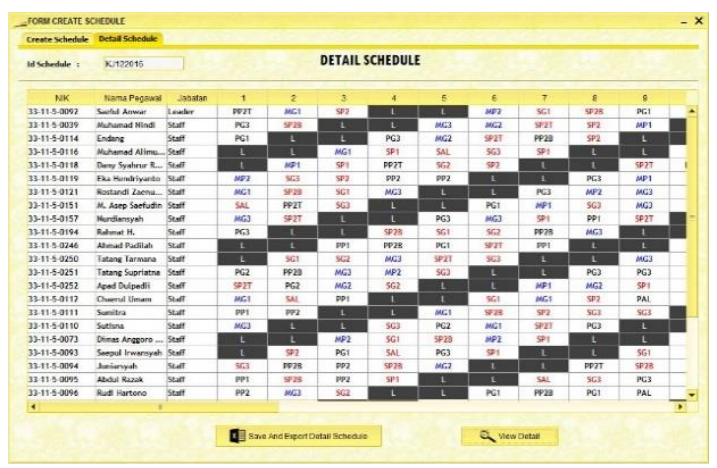

Fig. 3. The Generated shift schedule of the security officers.

\subsection{The Experiments}

The test is performed on Genetic Algorithm control parameters. It aims to measure the quality of a control parameter value in the program. Also, this test is intended to find the optimum value of a combination of control parameters. The parameters include crossover probability value $(\mathrm{Pc})$, mutation probability value $(\mathrm{Pm})$, iteration, and some individuals. Based on the verification by the expert, the test results are divided into three categories: Not Appropriate (NA), Less Appropriate (LA) and Appropriate (A). In this test, there are three stages of testing.

Table 1. The experiment results of the number of individual and number of iteration combination.

\begin{tabular}{ccccc}
\hline \# Individual & \# Iteration & Fitness & Times (seconds) & Result \\
\hline 10 & 10 & 6.87 & 21.74 & LA \\
10 & 20 & 9.91 & 28.61 & LA \\
10 & 40 & 11.96 & 36.93 & LA \\
10 & 50 & 1.06 & 53.10 & A \\
10 & 70 & 1.37 & 72.21 & A \\
20 & 10 & 1.04 & 37.28 & A \\
20 & 20 & 1.82 & 101.24 & LA \\
20 & 40 & 1.81 & 92.71 & LA \\
20 & 50 & 1.89 & 100.54 & A \\
20 & 70 & 1.02 & 138.12 & LA \\
40 & 10 & 1.28 & 104.07 & LA \\
40 & 20 & 1.76 & 109.93 & LA \\
40 & 40 & 1.79 & 363.42 & LA \\
40 & 50 & 2.42 & 223.70 & LA \\
40 & 70 & 2.51 & 232.89 & NA \\
50 & 10 & 26.36 & 77.11 & LA \\
50 & 20 & 4.80 & 129.82 & LA \\
50 & 40 & 9.61 & 321.49 & LA \\
50 & 50 & 18.53 & 363.17 & NA \\
50 & 70 & 31.02 & 382.45 & \\
\hline
\end{tabular}


The first stage is to find the best combination of the number of iteration and individual. In this test, the number of individuals used is 10, 20, 40 and 50. Iterations of 10, 20, 40, 50, 70. The values of crossover probability parameters $(\mathrm{Pc})$ and mutation probabilities $(\mathrm{Pm})$ are set by 0.5. Each time five tests are done.

Based on the result of the experiment, it is found that the best number of iteration and individual that produce the optimal schedule is when the number of iterations is 10 , and the number of individuals is 20 . From the first stage testing it can also be concluded that $20 \%$ of the schedule produced is appropriate (A), 65\% less appropriate (LA), 15\% is not appropriate (NA).

The second test is to find the best probability of crossover $(\mathrm{Pc})$ and the probability of mutations (Pm). In this test, the combination of the Pc and Pm's value are 0.9: 0.2, 0.7: 0.3, 0.3: $0.04,0.8: 0.05,0.8: 0.06$ with each of 4 tests. In accordance with the optimal number of individuals and the optimal iteration obtained at the first stage of testing, the second stage of testing using the number of individuals 20 and iteration 10. The results of the second test listed in Table 3.

Table 2. The experiment results of the probability of crossover $(\mathrm{Pc})$ and the probability of mutations (Pm).

\begin{tabular}{ccccccc}
\hline \# Individual & \# Iteration & $P c$ & $P m$ & Fitness & Time (seconds) & Result \\
\hline 20 & 10 & 0.9 & 0.2 & 1.40 & 35.97 & A \\
20 & 10 & 0.7 & 0.3 & 1.87 & 29.91 & NA \\
20 & 10 & 0.3 & 0.04 & 1.18 & 24.33 & LA \\
20 & 10 & 0.8 & 0.05 & 1.05 & 26.66 & NA \\
20 & 10 & 0.8 & 0.06 & 1.95 & 66.08 & A \\
20 & 10 & 0.7 & 0.5 & 1.43 & 32.44 & A \\
20 & 10 & 0.6 & 0.1 & 3.25 & 27.08 & A \\
20 & 10 & 0.9 & 0.4 & 1.29 & 65.96 & NA \\
20 & 10 & 0.6 & 0.3 & 2.19 & 61.02 & NA \\
20 & 10 & 0.8 & 0.5 & 3.04 & 82.41 & A \\
\hline
\end{tabular}

Based on the test results in Table 3, the best combination of Pc and Pm is 0.8 for Pc and 0.6 for Pm. From the second stage of testing it can also be concluded that $50 \%$ of the schedule produced is appropriate (A), $10 \%$ less appropriate (LA), $40 \%$ is not appropriate (NA).

Table 3. The experiment results of Pc and Pm value combination.

\begin{tabular}{ccccccc}
\hline \# Individual & \# Iteration & $P c$ & Pm & Fitness & Time (seconds) & Result \\
\hline 20 & 10 & 0.8 & 0.06 & 4.07 & 28.27 & NA \\
20 & 10 & 0.8 & 0.06 & 1.57 & 26.95 & $\mathrm{~A}$ \\
20 & 10 & 0.8 & 0.06 & 1.84 & 67.42 & $\mathrm{~A}$ \\
20 & 10 & 0.8 & 0.06 & 1.26 & 96.91 & $\mathrm{NA}$ \\
20 & 10 & 0.8 & 0.06 & 1.02 & 74.32 & $\mathrm{~A}$ \\
20 & 10 & 0.8 & 0.06 & 1.92 & 78.77 & $\mathrm{~A}$ \\
20 & 10 & 0.8 & 0.06 & 2.94 & 38.63 & $\mathrm{~A}$ \\
20 & 10 & 0.8 & 0.06 & 1.55 & 65.08 & $\mathrm{~A}$ \\
20 & 10 & 0.8 & 0.06 & 1.95 & 127.04 & $\mathrm{~A}$ \\
20 & 10 & 0.8 & 0.06 & 3.04 & 121.49 & $\mathrm{NA}$ \\
\hline
\end{tabular}


The $3^{\text {rd }}$ test is to against the number of individuals, number of iterations, $\mathrm{Pc}$ and $\mathrm{Pm}$ values. Furthermore, the repetition testing of these parameters to obtain the results at Table 4 .

Based on the test results using the best parameters, we can conclude that $70 \%$ of the schedule produced has been inappropriate (A) with the expectations of the user. However, as many as $30 \%$ of the schedule is still not appropriate (NA). Based on the time of the generating shift schedule process, on average it takes 72.48 seconds. It is much faster than the manual scheduling process, which takes several days. It helps 'Danru' in the scheduling process more efficient.

After testing the program with various parameters, it is necessary to evaluate the program that has been tested. Based on the results of the trial, there are some advantages and disadvantages.

With our proposed application, the scheduling process is faster than the manual way that normally takes up to one week. We only need about 1 to 3 minutes to make the schedule. The team commanders (Danru) is made easy in setting up a shift schedule. The system is easy to use because it has a user-friendly look for users. The schedule also can be stored directly in the database and the Excel format. The level of the accuracy of the scheduling process with the parameters that have been tested by $70 \%$.

Our proposed method also has disadvantages. The results given are not necessarily the same as the previous experiments because the Genetic Algorithm looks for a set of solutions randomly. Sometimes there are some shift errors on the part of officers. Often there is a nonconformity to the shift in the form of the same shift in a double state of 3 to 4 shifts in a row.

\section{Conclusions}

Based on the results of tests that have been done, it can be concluded that in general the problem of scheduling security officers at the Rawa Buntu Station can be solved by genetic algorithm method proposed. The Genetic Algorithm, in this case, is represented by an integer representation depicting the work shift of the security officer. The use of the double-point method in crossover process and random mutation method in the mutation process gives the optimal result. The next generation elitism update method generates good fitness value. Meanwhile, the form of chromosome used is adjusted by the state of the number of days in each month and the number of existing officers, making it more dynamic. The fitness value used is one divided by the (number of errors + value $\varepsilon$ ), where the value of $\varepsilon$ (epsilon) is obtained at random. The fitness value obtained with this formula, also makes the results of the fitness of each to be more varied.

The best schedule results were obtained at the time of trial with the value of the number of individual parameters of 20 , iteration as much as ten times, the probability value of crossover (Pc) of 0.8 and the probability value of mutation $(\mathrm{Pm})$ of 0.06 .

Meanwhile, the accuracy of the success rate of the scheduling result in shift scheduling application by using Baker's SUS selection method, double-point-crossover, random mutation, and elitism is $70 \%$.

\section{References}

[1]BPS DKI Jakarta, Statistik Transportasi DKI Jakarta 2015-2016. Jakarta: BPS Provinsi DKI Jakarta, 2016. 
[2]D. E. Goldberg, Genetic Algorithms in Search, Optimization and Machine Learning. Boston: Addison-Wesley Longman Publishing Co., Inc., 1989.

[3]D. E. Goldberg, K. Milman, and C. Tidd, "Genetic Algorithms: A Bibliography." University of Illinois at Urbana-Champaign, pp. 1-83, 1995.

[4]Sam'ani, "Rancang Bangun Sistem Penjadwalan Perkuliahan Dan Ujian Akhir Semester Dengan Pendekatan Algoritma Genetika,” Univ. Diponegoro, pp. 1-46, 2012.

[5]J. E. Baker, "Reducing bias and inefficiency in the selection algorithm," in the second international conference on genetic algorithms, 1987.

[6]T. Pencheva, K. Atanassov, and A. Shannon, "Modelling of a Stochastic Universal Sampling Selection Operator in Genetic Algorithms Using Generalized Nets," in 10th International Workshop on Generalized Nets, 2009, no. December, pp. 1-7.

[7]K. Leksakul and S. Phetsawat, "Nurse scheduling using genetic algorithm," Math. Probl. Eng., vol. 2014, 2014.

[8]B. Ardhianto, B. Pudjoatmodjo, and M. D. Suliiyo, "Implementasi Algoritma Genetika Pada Penjadwalan Sidang Tugas Akhir Fakultas Informatika," Universitas Telkom, 2014.

[9]H. P. Hariyadi, T. Widiyaningtyas, M. Z. Arifin, and S. Sendari, "Implementation of Genetic Algorithm to academic scheduling system," in 2016 IEEE Region 10 Conference (TENCON), 2016, pp. 2013-2016.

[10]D. D. P. Sari, W. F. Mahmudy, and D. E. Ratnawati, “Optimasi Penjadwalan Mata Pelajaran Menggunakan Algoritma Genetika ( Studi Kasus : SMPN 1 Gondang Mojokerto ),” Repos. J. Mhs. PTIIK Univ. Brawijaya, vol. 5, no. 80, 2015.

[11]E. B. Prasetyo, "Implementation of Genetic Algorithm and Artificial Neural Network In Lecture Scheduling In Faculty of Mathematics and Natural Science Universitas Gadjah Mada," Universitas Gajah Mada, 2014. 